\title{
Arbuscular mycorrhizal colonization in black poplar roots after defoliation by a non-native and a native insect
}

\author{
Elisa Zampieri ${ }^{(1)}$, Edoardo \\ Petrucco Toffolo ${ }^{(2)}$, Antonietta \\ Mello $^{(3)}$, Achille Giorcelli ${ }^{(4)}$, \\ Massimo Faccoli ${ }^{(2)}$, Raffaella \\ Balestrini $^{(3)}$, Paolo Gonthier ${ }^{(1)}$
}

\begin{abstract}
A major goal in ecology is to understand how interactions among organisms influence ecosystem services. This work compares the effects of two Lepidoptera defoliators, one non-native (Hyphantria cunea) and one native (Lymantria dispar) to Europe, on the colonization of black poplar (the Populus nigra clone "Jean Pourtet") roots by an arbuscular mycorrhizal (AM) symbiotic fungus (Funneliformis mosseae) in a pot experiment. The effects of defoliation have also been assessed on the expression of fungal and plant genes playing a role during symbiosis. Both control and defoliated poplars have shown a low level of mycorrhization. Additionally, neither the non-native nor the native insect seem to strongly affect the AM colonization, at least at the time of observation (eight days from the end of the defoliation). Concerning the gene expression analysis, our results suggest that defoliation does not influence neither the expression of genes coding for a fungal and a plant phosphate transporter nor that of a gene coding for a fungal ATPase, and that there were no differences between defoliation carried out by the non-native and the native insect.
\end{abstract}

Keywords: Exotic, Defoliators, Arbuscular Mycorrhizal Symbiosis, qPCR, Poplar, Gene Expression

\section{Introduction}

Terrestrial ecosystems can be roughly divided into above- and below-ground, linked together by plants (Wardle 2002). A major goal in ecology is to understand how interactions among organisms influence ecosystems (Bezemer \& Van Dam 2005). Invasive organisms - i.e. non-native organisms, which threaten ecosystems, habitat or indigenous species - are a major element of global change and are contributing to biodiversity loss, ecosystem degradation and impairment of ecosystem services world wide (Baker et al. 2005).

More than $90 \%$ of plants form root interactions with mycorrhizal fungi that provide the host plant with water and mineral nutrients and can lead to an improved tolerance against biotic and abiotic stresses (e.g., salinity, drought, heavy metals), in exchange for photoassimilates (Smith \& Read 2008). In particular, arbuscular mycorrhizal (AM) symbiosis involves fungi belonging to Glomeromycota (Schüssler et al. 2001) and the majority of land plants, including both important crop species, such as tomato, wheat, rice, maize, soybean, and forest tree species, such as poplars (Populus spp. - Tisserant et al. 2012). The root colonization process involves both epidermal and cortical cells, where the fungus develops inter- and intra-cellular hy-
(1) Dipartimento di Scienze Agrarie, Forestali e Alimentari (DISAFA), Università di Torino, l.go Paolo Braccini 2, 10095 Grugliasco, TO (Italy); (2) Dipartimento di Agronomia, Animali, Alimenti, Risorse naturali e Ambiente -Agripolis-, Università di Padova, v.le dell'Università 16, 35020 Legnaro, PD (Italy); (3) Istituto per la Protezione Sostenibile delle Piante, CNR, SS Torino, v.le Mattioli 25, I-10125 Torino (Italy); (4) CREA - Consiglio per la Ricerca in Agricoltura e l'Analisi dell'Economia Agraria - Unità di Ricerca per le Produzioni Legnose Fuori Foresta (CREA-PLF), str. Frassineto 35, 15033 Casale M.to, AL (Italy)

@ Paolo Gonthier (paolo.gonthier@unito.it), Raffaella Balestrini (raffaella.balestrini@ipsp. cnr.it)

Received: Nov 06, 2015 - Accepted: May 21, 2016

Citation: Zampieri E, Petrucco Toffolo E, Mello A, Giorcelli A, Faccoli M, Balestrini R, Gonthier P (2016). Arbuscular mycorrhizal colonization in black poplar roots after defoliation by a non-native and a native insect. iForest 9: 868-874. - doi: 10.3832/ifor1911-009 [online 2016-08-29]

Communicated by: Alberto Santini phae, coils, and arbuscules (Genre \& Bonfante 2005). Despite the improved mineral nutrition, AM fungi cause a significant carbon cost for the host plant, allocating up to $20 \%$ of the photosynthates (Saravesi et al. 2014). AM fungi are obligate biotrophs and they are thus not able to survive long periods without the host plant (Bécard et al. 2004). Enzymes for saprotrophic behavior are lacking in the genome of the AM fungus Rhizophagus irregularis, which has been recently sequenced (Tisserant et al. 2013). Over long-term, leaf herbivory (and clipping) may eventually result in reduced carbon accessibility for the host plant and fungal partners (Barto \& Rillig 2010, Saravesi et al. 2014), although, in spite of the re-growth of the above-ground tissue, carbon allocation to roots often increases immediately after defoliation, while allocation to shoots decreases (Dyer et al. 1991, Holland et al. 1996). Although the impact of leaf herbivory on colonization by mycorrhizal fungi has mainly been reported as negative, sometimes even positive or nil effects on fungal symbiosis have been detected (Gehring \& Whitham 1994, 2002, Cullings et al. 2001, Eom et al. 2001, Hokka et al. 2004, Kula et al. 2005, Pietikäinen et al. 2005, Walling \& Zabinski 2006, Gehring \& Bennett 2009, Saravesi et al. 2014, Trocha et al. 2015). It has been reported that the variability in responses might depend on the type and extent of defoliation, the duration of the experiment, the mycorrhizal type or plant species considered, the availability of soil nutrients or other not yet known factors (Gehring \& 
Whitham 2002, Gehring \& Bennett 2009). Barto \& Rillig (2010) conducted a metaanalysis study, focusing on the sensitivity of $\mathrm{AM}$ and ectomycorrhizal (ECM) colonization of roots to the removal of leaves or shoots by herbivory or clipping. Meta-analysis results showed that the carbon-limitation hypothesis of reduced mycorrhizal colonization following removal of aboveground biomass was generally not supported, and that herbivory (or clipping) did not reduce mycorrhizal colonization by biologically meaningful levels in many types of plants (Barto \& Rillig 2010). More recently, Saravesi et al. (2014) reported a different effect of host plant defoliation on root AM and dark septate endophyte (DSE) fungi colonization. In particular, negative impacts on AM colonization and a slightly positive impact on DSE colonization were observed, suggesting divergent ecological roles of the two fungal associates in the plant carbon economy.

The increasing threat of invasive species, among which are several defoliators, raises a question about their possible impact on the components of native ecosystems (Kenis et al. 2009). In Europe, Hyphantria cunea Drury, a moth native to North America, became invasive in the 1940s (Warren \& Tadic 1970). Being a polyphagous defoliator, it feeds on hundreds of host plants, including black poplars. P. nigra L. is also a host plant for native defoliators, such as Lymantria dispar L. In a scenario where losses of above-ground biomass might impact mycorrhizal response as previously reported (Gehring \& Whitham 2002, Gehring \& Bennett 2009), the issue is whether invasive defoliators could play a role in affecting native ecosystem components such as AM fungi.

In this work we compare the effects of two Lepidoptera defoliators, a species nonnative to Europe, $\mathrm{H}$. cunea, and a native species, $L$. dispar, on black poplar (the $P$. nigra L. clone "Jean Pourtet") roots colonized by the AM fungus Funneliformis mosseae (T.H. Nicolson \& Gerd.) C. Walker \& A. Schüßler 2010. In particular, we assessed the AM fungal colonization in the black poplar roots and the expression of fungal genes coding for a fungal amino acid permease (GmosAAP1), two $\mathrm{H}^{+}$-ATPases (GmHA5, GmPMA1) and a phosphate transporter (GmosPT), as well as of a plant PT gene (PopPT) which have a putative role during symbiosis. The effects of both partial and total defoliation by larvae of the two defoliators have been evaluated.

\section{Material and methods}

\section{Mycorrhization of Populus nigra with Funneliformis mosseae}

Cuttings of the P. nigra clone "Jean Pourtet" were harvested in January 2014 at the CREA-PLF (Casale Monferrato, Italy). They were kept in tap water for 5/7 days and then planted in pots $(10 \times 10 \times 17 \mathrm{~cm})$ containing quartz sand previously sterilized at
$180{ }^{\circ} \mathrm{C}$ for 3 h. For one month, they were watered twice a week with tap water in order to obtain shoots and roots.

Forty-five seedlings were then inoculated with Funneliformis mosseae BEG 12 (formerly Glomus mosseae) inoculum (MycAgro Lab, France), by mixing the inoculum with sterile quartz sand $(30 \% \mathrm{v} / \mathrm{v})$. All plants were watered three times a week with tap water, and kept in a greenhouse for approximately 75 days, following the natural photoperiod (from March to June 2014).

\section{Defoliation of Populus nigra seedlings}

The defoliation occurred between the $24^{\text {th }}$ of June and the $16^{\text {th }}$ of July 2014 . The potted plants were kept in the field at Agripolis campus (Legnaro, Italy) inside cages to protect them from insect attack, under conditions that mimic the natural ones. Five theses were considered: undefoliated control plants, partial and total defoliation by $\mathrm{H}$. cunea and partial and total defoliation by L. dispar. In the partial treatment defoliation, about $50 \%$ of the leaves was exposed to defoliation, whereas in the total treatment defoliation experiment the whole foliage was exposed to defoliation. To achieve this, the half-lower part of plant bearing about $50 \%$ of leaves was enclosed in the mesh bag in the partial defoliation thesis and the entire plant in the total defoliation thesis. Each thesis included nine replicates. Each plant had a single pot and was enclosed, kept separately from the others, in a mesh bag, where 5 larvae (fourth-fifth instars) of $H$. cunea or L. dispar were placed for partial defoliation and 10 larvae of $H$. cunea or $L$. dispar for total defoliation experiments, respectively. The plants were watered every two days and checked, evaluating the degree of defoliation and replacing any dead larvae. The experiment was stopped at the same time for all the plants.

\section{Estimation of the mycorrhization}

All plants were unrooted after eight days from the end of the defoliation treatment, in order to assess the effects of the pests on the mycorrhizal colonization. The whole root apparatus from each plant was washed under tap water and divided into two parts: one part was used to estimate the level of mycorrhiza formation (see below), while the other part was frozen in liquid nitrogen and kept at $-80^{\circ} \mathrm{C}$ for subsequent molecular analysis. Colonization was assessed using the method described by Trouvelot et al. (1986). Twenty-cm-long root segments were sampled from each root system, cleared in $10 \% \mathrm{KOH}$ at $45^{\circ} \mathrm{C}$ for $1 \mathrm{~h}$, washed twice in $10 \% \mathrm{KOH}$ for $24 \mathrm{~h}$, stained with $0.1 \%$ cotton blue in lactic acid (Lingua et al. 2008), and mounted on slides.

\section{Nucleic acid extraction and cDNA conversion}

The DNA extraction was performed on about $100 \mathrm{mg}$ of leaves and of roots using the DNeasy Plant Mini Kit ${ }^{\oplus}$ (Qiagen, Valencia, CA, USA) according to the manufacturer's instructions.

The RNA was extracted from about 100 mg of roots using the "pine-tree method" (Chang et al. 1993). After extraction, RNA was cleaned of DNA, using Promega DNase (RQ1 RNase-Free DNase ${ }^{\circledR}$, Promega Corp., Madison, WI, USA), and then measured using a NanoDrop ${ }^{\oplus}$ (ThermoScientific, Hudson, NH, USA). The absence of genomic DNA was verified through one-step retrotranscription PCR (One-Step RT-PCR, Qiagen) with primers (Gmostef1, Gmostef2) previously designed for the $F$. mosseae elongation factor reference gene (Cappellazzo et al. 2008). Briefly, the same extracted RNA was used as template for retro-transcription and for PCR amplification or for PCR amplification only (RT- reactions). The absence of signal after PCR amplification without retrotranscription was regarded as absence of DNA. Total RNA for each sample was used to synthesize the CDNA, according to the SuperScript II Reverse Transcriptase ${ }^{\circledR}$ (Invitrogen, Carlsbad, CA, USA) procedure using random primers.

\section{Selected genes and primers}

The fungal genes selected for the analysis were an amino acid permease (GmosAAP1

Cappellazzo et al. 2008), a phosphate transporter (GmosPT - Balestrini et al. 2007) and two different $\mathrm{H}^{+}$-ATPases (GmHA5, GmPMA1 - Requena et al. 2003). The fungal reference gene was the elongation factor (Gmostef - Cappellazzo et al. 2008). Concerning the plant, an elongation factor 1 , beta subunit (PopEF1) was used as reference gene (Regier et al. 2009), in addition to a phosphate transporter (PopPT) for which the primers were designed using the web-interface program Primer3Plus (http://www.bioinformatics.nl/cgi-bin/prim er3plus/primer3plus.cgi/). To this aim, the mycorrhizal-inducible Solanum lycopersicum phosphate transporter 4 (LePT4 accession AAV97730.2) was used to search the homologous in the genome of $P$. trichocarpa (http://phytozome.jgi.doe.gov/pz/ portal.html\#! info?alias=Org_Ptrichocarpa Tuskan et al. 2006). Among the P. trichocarpa homologous sequences identified using the tomato LePT4 sequence, the Potri.015G022800.1 was the best hit. The poplar and tomato aminoacid sequences showed $76 \%$ of identity and $98 \%$ of coverage with 0.0 of E-value. In addition, the poplar aminoacid sequence showed $74 \%$ of identity and $98 \%$ of coverage with 0.0 of Evalue with the high affinity inorganic phosphate transporter of Medicago truncatula (accession XP_013466381.1), which corresponds to the mycorrhiza-inducible MtPT4 (accession AAM76744.1).

The primers used in this work are listed in Tab. 1. Fungal primers were tested on poplar DNA in order to verify the absence of cross-amplification. The primers for PopPT were tested in silico to verify the 
Tab. 1 - List of the primers used in the study and their temperature of annealing (Ta).

\begin{tabular}{llll}
\hline Name & Gene Function & Reference & Sequence \\
\hline $\begin{array}{l}\text { GmosPT For } \\
\text { GmosPT Rev }\end{array}$ & Pi transporter & Balestrini et al. 2007 & ACTGTTGGCGCTTAGTGCTTGG \\
GmPMA1F3 & ${ }^{\circ}$ C) & CAGCCCAACTTGATTTTGGTACG \\
GmPMA1R1 & & Requena et al. 2003 & CCAGTCAAGAAAGTTCCCAAG \\
GmHA5up1 & & & CACGTTCAGCTGCTGATATCG \\
GmHA5up3 & & & AATAATGTCTCCGAGGCGAGG \\
Gmostef1 & Elongation factor & TTGAAGTAGCTTGCCTTTTCGC \\
Gmostef2 & & Cappellazzo et al. 2008 & GCAGAACGTGAGCGTGGTAT \\
$\begin{array}{l}\text { GmosAAP1 } \\
\text { GmosAAP2 }\end{array}$ & Amino acid permease & ACCAGTACCGGCAGCAATAA \\
\hline $\begin{array}{l}\text { PopPT4for } \\
\text { PopPT4rev }\end{array}$ & Poplar phosphate & & TACTCCTCCCACCGATTACG \\
EF1 F & transporter & & CCGATGATGAGATAGCCGAT \\
EF1 R & Poplar elongation factor 1, & Regier et al. 2009 & TACGCAACCTCAGGCGGATT \\
\hline
\end{tabular}

amplification on the target gene. In addition, PCR fragment has been sequenced at BMR Genomics S.r.L. (Padua, Italy).

\section{Relative fungal DNA abundance}

To evaluate the relative fungal abundance in poplar roots, quantitative PCR ( $\mathrm{PPCR}$ ) was carried out with Connect ${ }^{\mathrm{TM}}$ Real-Time PCR Detection System (Bio-Rad Laboratories, Hercules, CA, USA). Each PCR reaction was conducted on a total volume of $10 \mu \mathrm{l}$, containing $1 \mu \mathrm{l}$ DNA $\left(4.5 \mathrm{ng}^{\mathrm{l}} \mathrm{l}^{-1}\right), 5 \mu \mathrm{l}$ SsoAdvanced $^{\mathrm{TM}}$ Universal SYBR ${ }^{\circledast}$ Green Supermix (Bio-Rad Laboratories), $3.4 \mu$ l of water and $0.3 \mu \mathrm{l}$ of each primer $(10 \mu \mathrm{M})$, using a 96 well plate. The reference genes for the fungus (elongation factor - Cappellazzo et al. 2008) and for the plant (elongation factor 1, subunit beta - Regier et al. 2009) are listed in Tab. 1. The following PCR program, which includes the calculation of a melting curve, was used: $95^{\circ} \mathrm{C}$ for $30 \mathrm{~s}, 45$ cycles of $95{ }^{\circ} \mathrm{C}$ for $10 \mathrm{~s}$, the optimal annealing temperature for $30 \mathrm{~s}$, ramp from 65 to $93{ }^{\circ} \mathrm{C}$ with a temperature increment of $0.5^{\circ} \mathrm{C}$ and a read plate every $2 \mathrm{~s}$. All the reactions were performed for three biological and three technical replicates. The baseline range and $\mathrm{Ct}$ values were automatically calculated using the Bio-Rad CFX Manager software. The fungal reference gene expression was normalized to that of the plant reference gene by subtracting the $\mathrm{Ct}$ value of the plant reference gene from the $\mathrm{Ct}$ value of the fungal reference gene and obtaining a $\Delta \mathrm{Ct}$. The measure of the average PCR efficiency was carried out using the software PCR miner (Zhao \& Fernald 2005), showing comparable values for the two genes (0.87-0.88). The Kruskal Wallis test was carried out using the free software Past version 3.07 (http://folk.uio.no/ ohammer/past/), with a 0.05 cut-off level of significance.

\section{Gene expression analysis}

Gene expression analyses on plant and fungal genes were performed by quantitative real-time (RT-qPCR) on the cDNAs produced starting from the extracted RNAs, using the same machine, the same mix and the same PCR program described above. The primers used are listed in Tab. 1. In order to compare the data from different PCR runs or CDNA samples, the $C t$ values of all the genes were normalized to the $\mathrm{Ct}$ value of the reference. Candidate gene expression was normalized to that of the reference gene by subtracting the $\mathrm{Ct}$ value of the reference gene from the $\mathrm{Ct}$ value of the candidate gene without efficiency correction, from equation $2^{-\Delta \Delta C T}$ (Livak \& Schmittgen 2001), where $\Delta \Delta C t$ represents the $\Delta$ Ct sample - $\Delta$ Ct control (control plants). The Kruskal Wallis test was carried out using Past version 3.07, with a 0.05 cut-off level of significance.

\section{Results and discussion}

It has been reported that herbivores, such as insects, could have contradictory effects on the mycorrhization (Barto \& Rillig 2010, Saravesi et al. 2014). In this work, the effect of a non-native defoliator on poplar colonization by an AM fungus was compared with that induced by an ecologi- cally related native one, both in total and in partial defoliation. The consequences of defoliation were evaluated at the level of mycorrhizal colonization and on the expression of specific genes, which play a role in symbiosis functioning.

All poplar leaves were defoliated similarly by the two insects, resulting in a $50 \%$ defoliation in the partial defoliation experiment and in a $100 \%$ defoliation in the total defoliation experiment.

\section{Extent of colonization}

AM fungus colonization occurred in both control and defoliated poplars, although it never reached very high levels, as previously reported on the same poplar clone (Lingua et al. 2008) and on P. alba (Lingua et al. 2012). The colonization was very patchy with some fragments very highly colonized and the most uncolonized. However, morphological observations in the colonized fragments allowed to identify the presence of the typical structures of the symbiosis (such as inter- and intracellular

Tab. 2 - Relative DNA quantities of F. mosseae obtained from the qPCR assays on the roots of $P$. nigra. The $C t$ value was the mean of three $q P C R$ runs for each DNA sample both for the fungus ( $F$. mosseae) and for the plant (P. nigra). $(\Delta \mathrm{Ct})$ : $\mathrm{Ct}$ Cmostef - $\mathrm{Ct}$ PopEF1. $\Delta$ Cts followed by the same letter are not significantly different after the least significant difference test $(p>0.05)$.

\begin{tabular}{lccc}
\hline Biological replicate & Ct Gmostef & Ct PopEF1 & $\Delta \mathrm{Ct}$ \\
\hline Control plant_C8 & 32.91 & 24.58 & $8.34^{\mathrm{a}}$ \\
Control plant_C9 & 30.20 & 24.31 & $5.89^{\mathrm{a}}$ \\
Control plant_C21 & 30.10 & 23.55 & $6.55^{\mathrm{a}}$ \\
\hline Hyphantria cunea_100_1 & 31.46 & 24.25 & $7.22^{\mathrm{a}}$ \\
Hyphantria cunea_100_2 & 28.01 & 23.94 & $4.07^{\mathrm{a}}$ \\
Hyphantria cunea_100_28 & 28.71 & 24.23 & $4.48^{\mathrm{a}}$ \\
Hyphantria cunea_50_7 & 30.31 & 24.91 & $5.39^{\mathrm{a}}$ \\
Hyphantria cunea_50_12 & 30.36 & 23.86 & $6.50^{\mathrm{a}}$ \\
Hyphantria cunea_50_26 & 36.15 & 23.42 & $12.73^{\mathrm{a}}$ \\
Lymantria dispar_100_5 & 29.33 & 25.21 & $4.13^{\mathrm{a}}$ \\
Lymantria dispar_100_11 & 32.17 & 24.85 & $7.32^{\mathrm{a}}$ \\
Lymantria dispar_100_16 & 31.54 & 25.28 & $6.27^{\mathrm{a}}$ \\
Lymantria dispar_50_4 & 31.63 & 23.83 & $7.80^{\mathrm{a}}$ \\
Lymantria dispar_50_6 & 31.67 & 24.86 & $6.81^{\mathrm{a}}$ \\
Lymantria dispar_50_19 & 29.87 & 25.07 & $4.81^{\mathrm{a}}$ \\
\hline
\end{tabular}



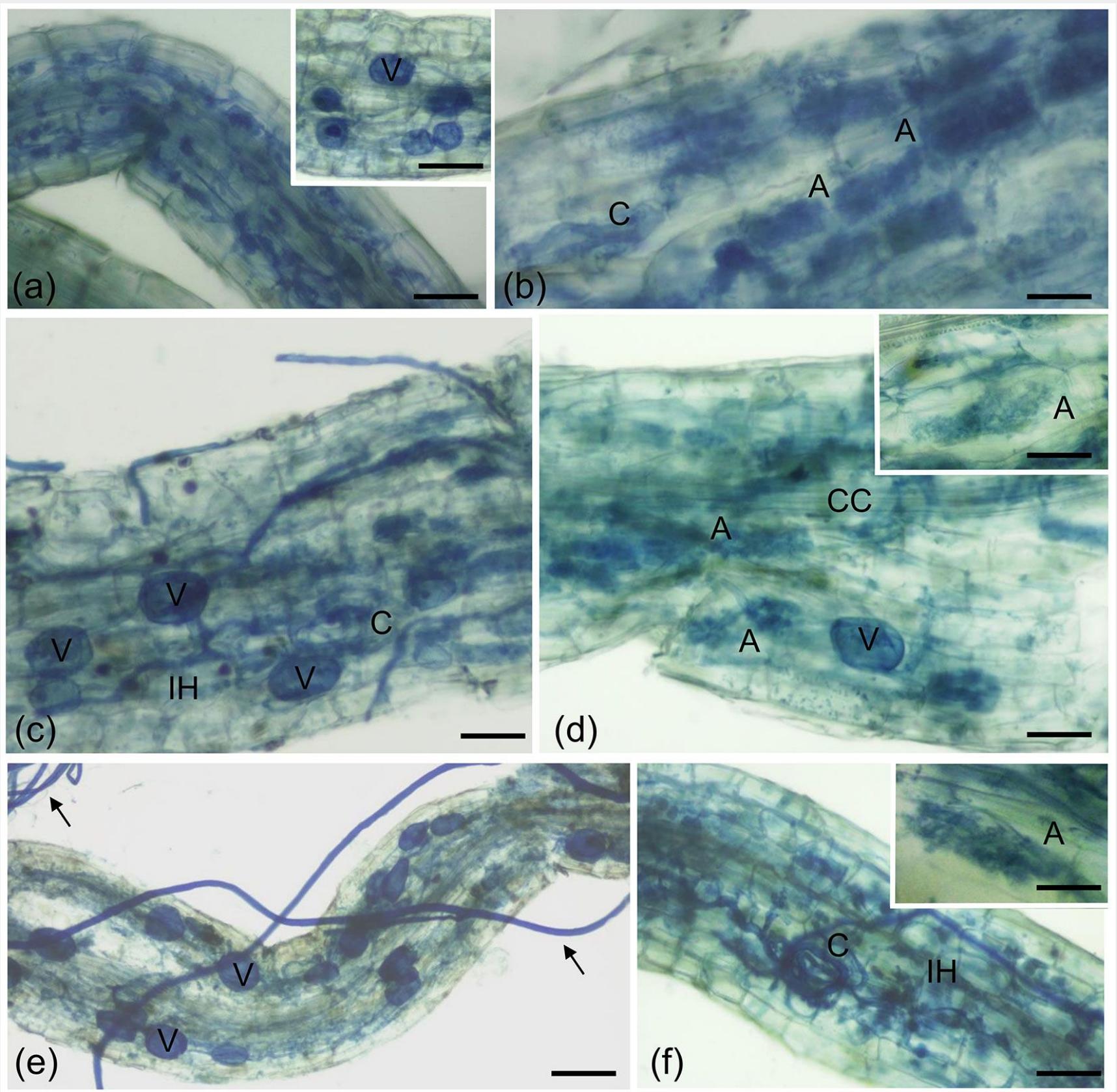

Fig. 1 - Cotton blue staining of poplar roots colonized by F. mosseae. Typical AM fungal structures, stained with $0.1 \%$ cotton blue, developed in P. nigra "Jean Pourtet" fine roots from F. mosseae-colonized control (a, b) and defoliated plants, with both $\mathrm{H}$. cunea (c, d) and L. dispar (e, f). (a) Intracellular structures (intracellular hyphae and collapsed arbuscules) are visible in a poplar root. Bar $=80$ $\mu \mathrm{m}$. Inset: Detail of a root region where vesicles $(\mathrm{V})$ are visible. Bar $=80 \mu \mathrm{m}$. (b) Intracellular arbuscules $(\mathrm{A})$ are present in the root cortex. C, coil. Bar $=50 \mu \mathrm{m}$. (c) Root colonization after defoliation with $\mathrm{H}$. cunea. Vesicles $(\mathrm{V})$ along the intercellular hyphae $(\mathrm{IH})$ pervaded the root apparatus. Bar $=50 \mu \mathrm{m}$. (d) Arbuscules (A) are visible, as expected, in the root cortex. CC, central cylinder; V, vesicle. Bar $=50 \mu \mathrm{m}$. Inset: Detail of an arbuscule. Bar $=40 \mu \mathrm{m}$. (e) Root colonization after defoliation with L. dispar. Inter- and intracellular hyphae and vesicles $(V)$ pervaded the root apparatus. Arrows point on extra-radical mycelium. Bar $=90 \mu \mathrm{m}$. (f) A coil (C) is evident among the several inter-and intracellular hyphae $(\mathrm{IH})$. Bar $=60 \mu \mathrm{m}$. Inset: Detail of an arbuscule. Bar $=40 \mu \mathrm{m}$.

hyphae, coils, vesicles and arbuscules) in the roots of plants, regardless of the thesis (Fig. 1). Here, the low level of colonization, as well as the quality of the root segments after the staining, made morphological quantification difficult, and therefore the presence of the AM fungus has been quantified by calculating the relative fungal DNA abundance (Tab. 2). Quantitative PCR $(\mathrm{QPCR})$ results showed that fungal $\mathrm{Cts}$ are higher than plant ones in all the theses, suggesting that fungal DNA is in lower amount than the plant one as previously described (Li et al. 2008). Statistical analysis showed that there was no significant difference in the amount of fungal DNA in the roots of plants from the different theses $(p>0.05)$.

\section{Gene expression analysis}

To verify the effect of defoliation on AM symbiosis functioning, the expression of fungal genes, for which a previous role during symbiosis was reported, has been evaluated (Requena et al. 2003, Balestrini et al. 2007, Cappellazzo et al. 2008, Gomez-Ariza et al. 2009). Due to their role in symbiosis, fungal and plant PT genes are considered as key genes for the symbiosis (Balestrini et al. 2007, Bucher 2007). Together with the expression of fungal genes, we analyzed a poplar PT gene (PopPT), selected on the basis of the homology with a 
tomato PT gene (LePT4), which is considered as a marker for a functional symbiosis (Nagy et al. 2005, Xu et al. 2007).

The $\Delta \mathrm{Ct}$ for each biological replicate was shown in Tab. S1 in Supplementary material, coupled with mean and standard deviation (SD). In Tab. S2 (Supplementary material) the $\mathrm{Ct}$ values coupled with mean and standard deviation (SD) were shown for each gene and for each technical replicate.

Starting from the fungal genes, Gmos$A A P 1$ gene expression was detected in onestep RT-PCR (data not shown), while it was not possible to quantify its transcripts in RT-qPCR. Cappellazzo et al. (2008) demonstrated that this gene is expressed in the extra-radical mycelium, but not in the intraradical one, suggesting a role in the first steps of amino acid achievement and in favoring a direct amino acid uptake from the soil. In poplar-F. mosseae association, it was not possible to quantify its expression by RT-qPCR, while a signal has been detected by one-step RT-PCR. This may suggest that this $A M$ fungus can produce only a small quantity of extra-radical mycelium in our system or that only a little amount of extra-radical mycelium remained attached to the roots after the repotting. Concerning the two $\mathrm{H}^{+}$-ATPases, $\mathrm{GmHA} 5$ was expressed in all the five theses and no different expression was assessed in control and defoliated plants ( $p>0.05$ - Fig. $2 b$ ), while GmPMA1 transcripts were detected only in one replicate of the defoliated samples using one-step RT-PCR (data not shown), and not in RT-qPCR. Looking at the data previously reported by Requena et al. (2003), GmHA5 showed a very low expression during non-symbiotic growth and a highly induced expression in mycorrhizal roots and in extra-radical hyphae. GmPMA1 was on the contrary more expressed in the pre-symbiosis and less in the late stages of symbiosis, in agreement with our results. $\mathrm{H}^{+}$-ATPases play a role in the establishment of an electrochemical gradient, necessary for the transport of nutrients across the plasma membrane in both fungi and plants, but each isoform could be engaged at different developmental stages, probably in function of the different necessities in the symbiosis (Requena et al. 2003).

In this study, no significant differences in GmosPT expression were observed between the control and defoliated samples ( $p>0.05$ - Fig. $2 a$ ), suggesting that the feeding activity of insects has no influence on the phosphate $(\mathrm{Pi})$ transport by the fungus. A role and a control action in $\mathrm{Pi}$ transfer by GmosPT was suggested and its expression was reported both in extra- and intra-radical mycelium (Benedetto et al. 2005). Our results suggest that defoliation does not influence the expression of this fungal gene and that there are no differences between defoliation carried out by the non-native or the native insect considered, at least at the sampling time (eight days after the end of the defoliation). As regards the plant, the expression of the

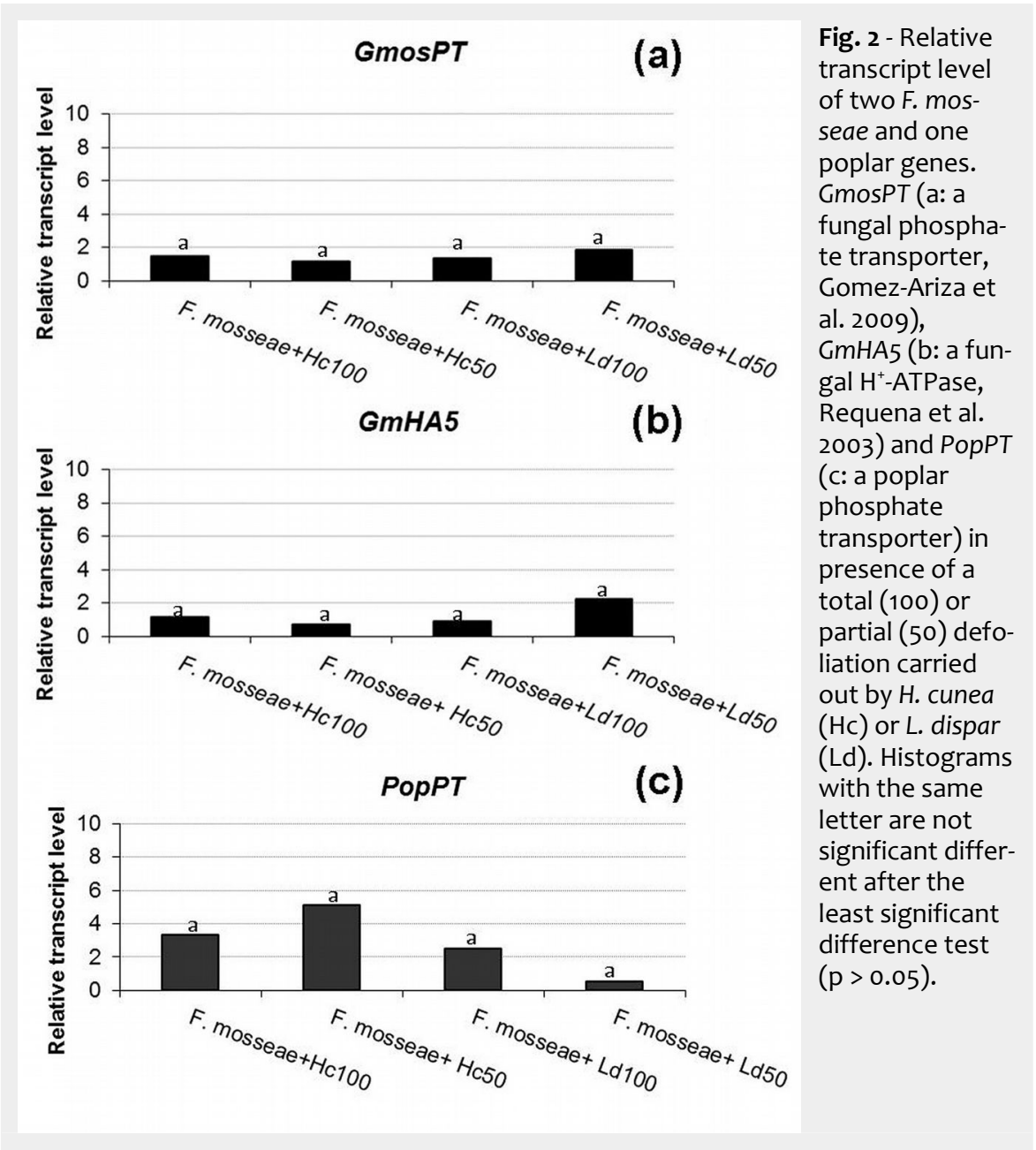

selected poplar PT gene was not affected by the defoliation in any of the theses (Fig. 2c). In tomato mycorrhizal roots LePT4 transcripts have been specifically detected in arbuscule-containing cells together with other tomato PT genes and GmosPT (Balestrini et al. 2007, Gomez-Ariza et al. 2009), suggesting that in arbusculated cells the fungus can compete with the plant for the Pi uptake. Taken together, the results on PT genes, which are considered as markers of a functional symbiosis, confirm the quantitative results, showing no differences in the mycorrhization among the samples.

Additionally, neither the non-native nor the native insect seem to strongly affect the AM colonization, at least at the time of observation.

Previous studies on the impact of defoliation on roots colonized by $A M$ fungi reported controversial results. In Lotus tenuis, the reduction in the photosynthetic capacity by defoliation did not change the root length colonized by AM fungi and the proportion of root colonized by arbuscules, while it decreased vesicular colonization. García \& Mendoza (2012) suggested that the strategy of the AM fungus consisted in investing more of the $C$ resources to preferentially maintain the arbuscules and the inoculum density in the soil by exporting $C$ compounds to retain extra- radical structures such as spores and the hyphal network. In woody species, the extensive below-ground carbon reserves could limit the effects of defoliation on mycorrhizal colonization, even after the loss of large amounts of above-ground biomass (Kosola et al. 2004). In particular, the results of a field experiment with the hybrid poplar Populus $x$ canadensis Moench "Eugenei" showed that neither ECM nor AM colonization were affected by $L$. dispar defoliation during two years. Barto \& Rillig (2010), through a meta-analysis of 99 experiments from 33 publications, suggested that, in contrast with the carbon-limitation hypothesis, herbivory did not reduce mycorrhizal colonization by biologically significant levels in the majority of plants, including perennial grasses and forbs. Recently, Trocha et al. (2015) have not found changes in the composition of ECM communities of Fagus sylvatica and Pinus sylvestris after damages, including defoliation. On the contrary, Markkola et al. (2004) and Saravesi et al. (2008) found changes in the ECM composition when Betula pubescens or $P$. sylvestris were defoliated, suggesting that high-biomass ECM fungal species need great quantities of carbon because they found a reduction of these fungi after defoliation. 


\section{Conclusions}

Although the poplar roots showed a low level of AM fungal colonization in all the theses, our results suggest that neither the non-native nor the native insect considered seem to strongly affect the AM colonization, at least in our conditions and sampling time. Two levels of defoliation (total and partial) were considered and the impact of the defoliators on the colonization by an AM fungus was investigated, showing the expression of fungal and plant genes putatively involved in symbiosis functioning. No defoliation theses showed any significant differences compared to the undefoliated ones. Despite several studies simulated herbivory effects on plants using mechanical defoliation or included mechanically defoliated control plants, this approach is deemed appropriate when studying simple biotic interactions, but not necessarily for complex interactions including different trophic levels (Hjältén 2004, Lehtilä \& Boalt 2004), as the ones investigated. Although most of the papers published on AM symbiosis report open field experiments, pot experiments in semi-controlled conditions, like those performed in this work, have allowed to study some of the mechanisms involved in plant-AM fungi interaction under defoliation conditions. However, it cannot be excluded that a longer time after defoliation would be needed to affect fungal colonization. In addition, an analysis of other fungal genes (such as a hexose transporter gene) could be useful to obtain a more complete picture, but unfortunately the F. mosseae genome has not been sequenced and the sequences available are still limited. Interestingly, differential impact of seasonal defoliation on root fungal symbionts has also been reported (Saravesi et al. 2008). It could be interesting to compare the data obtained in this work employing other defoliators, or to study the AM symbiosis in defoliated poplars directly in nature. As suggested by Saravesi et al. (2008), different herbivore organisms, which have dissimilar feeding regimes during the growing season, could have diverse effects on the composition or condition of fungal symbionts. Data presented in this study improve the knowledge on differential effect that invasive organisms may have compared to native ones on plant symbionts, an issue recently reported for plant pathogens (Sillo et al. 2015), but rarely investigated for defoliators.

\section{Acknowledgements}

This work was supported by the Italian Ministry of Education, University and Research, within the FIRB program (grant number RBFR1280NN).

The Authors would like to thank Maria Teresa Della Beffa, Mara Novero and Alessandra Salvioli (Dipartimento di Scienze della Vita e Biologia dei Sistemi, University of Turin, Italy) for the help in mycorrhizal plant preparation and the helpful sugges- tions on discussion and presentation of $A M$ fungal colonization and molecular data, respectively.

\section{References}

Baker R, Cannon R, Bartlett P, Barker IA (2005). Novel strategies for assessing and managing the risks posed by invasive alien species to global crop production and biodiversity. Annals of Applied Biology 146: 177-191. - doi: 10.1111/j.17447348.2005.040071.x

Balestrini R, Gómez-Ariza J, Lanfranco L, Bonfante $P$ (2007). Laser microdissection reveals that transcripts for five plant and one fungal phosphate transporter genes are contemporaneously present in arbusculated cells. Molecular Plant Microbe Interaction 20: 1055-1062. doi: 10.1094/MPMI-20-9-1055

Barto EK, Rillig MC (2010). Does herbivory really suppress mycorrhiza? A meta-analysis. Journal of Ecology 98: 745-753. - doi: 10.1111/j.1365-2745. 2010.01658.x

Bécard G, Kosuta S, Tamasloukht M, Sejalon-Delmas N, Roux C (2004). Partner communication in the arbuscular mycorrhizal interaction. Canadian Journal of Botany 8: 1186-1197. - doi: 10.1139/b04-087

Benedetto A, Magurno F, Bonfante P, Lanfranco $L$ (2005). Expression profiles of a phosphate transporter gene (GmosPT) from the endomycorrhizal fungus Glomus mosseae. Mycorrhiza 5: 620-627. - doi: 10.1007/s00572-005-0006-9

Bezemer TM, Van Dam NM (2005). Linking aboveground and belowground interactions via induced plant defenses. Trends in Ecology and Evolution 20: 617-624. - doi: 10.1016/j.tree. 2005.08.006

Bucher M (2007). Functional biology of plant phosphate uptake at root and mycorrhiza interfaces. New Phytologist 173: 11-26. - doi: 10.1111/j. 1469-8137.2006.01935.x

Chang S, Puryear J, Cairney J (1993). Simple and efficient method for isolating RNA from pine trees. Plant Molecular Biology Reporter 11: 113116. - doi: $10.1007 / B F 02670468$

Cappellazzo G, Lanfranco L, Fitz M, Wipf D, Bonfante $P$ (2008). Characterization of an amino acid permease from the endomycorrhizal fungus Glomus mosseae. Plant Physiology 147: 429437. - doi: 10.1104/pp.108.117820

Cullings KW, Vogler DR, Parker VT, Makhija S (2001). Defoliation effects on the ectomycorrhizal community of a mixed Pinus contortal Picea engelmannii stand in Yellowstone Park. Oecologia 127: 533-539. - doi: 10.1007/s0044200 00610

Dyer MI, Acra MA, Wang GM, Coleman DC, Freckman DW, McNaughton SJ, Strain BR (1991). Source-sink carbon relations in two Panicum coloratum ecotypes in response to herbivory. Ecology 72: 1472-1483. - doi: 10.2307/194 1120

Eom AH, Wilson GWT, Hartnett DC (2001). Effects of ungulate grazers on arbuscular mycorrhizal symbiosis and fungal community structure in tallgrass prairie. Mycologia 93: 233-242. doi: $10.2307 / 3761643$

García I, Mendoza R (2012). Impact of defoliation intensities on plant biomass, nutrient uptake and arbuscular mycorrhizal symbiosis in Lotus tenuis growing in a saline-sodic soil. Plant Biol- ogy 14: 964-971. - doi: 10.1111/j.1438-8677.2012. 00581.x

Gehring CA, Bennett AE (2009). Mycorrhizal fungal-plant-insect interactions: the importance of a community approach. Environmental Entomology 38: 93-102. - doi: 10.1603/022.038.0111 Gehring CA, Whitham TG (1994). Interactions between aboveground herbivores and the mycorrhizal mutualists of plants. Trends in Ecology and Evolution 9: 251-255. - doi: 10.1016/01695347(94)90290-9

Gehring CA, Whitham TG (2002). Mycorrhizaeherbivore interactions: population and community consequences. In: "Mycorrhizal Ecology" (van der Heijden MGA, Sanders IR eds). Springer, Berlin, Germany, pp. 295-320. - doi: 10.1007/978-3-540-38364-2_12

Genre A, Bonfante P (2005). Building a mycorrhizal cell: how to reach compatibility between plants and arbuscular mycorrhizal fungi. Journal of Plant Interaction 1: 3-13. - doi: 10.1080/ 17429140500318986

Gomez-Ariza J, Balestrini R, Novero M, Bonfante $P$ (2009). Cell-specific gene expression of phosphate transporters in mycorrhizal tomato roots. Biology and Fertility of Soils 45: 845-853. - doi: 10.1007/s00374-009-0399-2

Hjältén J (2004). Simulating herbivory: problems and possibilities. In: "Insects and Ecosystem Function" (Weisser WW, Siemann E eds). Springer-Verlag, Berlin Heidelberg, Germany, pp. 243-255. - doi: 10.1007/978-3-540-74004-9_12 Hokka V, Mikola J, Vestberg M, Setala H (2004). Interactive effects of defoliation and an $A M$ fungus on plants and soil organisms in experimental legume-grass communities. Oikos 106: 73-84. - doi: 10.1111/j.0030-1299.2004.12963.x Holland JN, Cheng W, Crossley DA (1996). Herbivore-induced changes in plant carbon allocation: assessment of below-ground C fluxes using carbon-14. Oecologia 107: 87-94. - doi: 10.1007/BF00582238

Kenis $M$, Auger-Rozenberg MA, Roques A, Timms L, Péré C, Cock MJ, Settele J, Augustin S, Lopez-Vaamonde C (2009). Ecological effects of invasive alien insects. Biological Invasions 11: 21-45. - doi: 10.1007/s10530-008-9318-y

Kosola KR, Durall DM, Robertson GP, Dickmann DI, Parry D, Russell CA, Paul EA (2004). Resilience of mycorrhizal fungi on defoliated and fertilized hybrid poplars. Canadian Journal of Botany 82: 671-680. - doi: 10.1139/bo4-038

Kula AAR, Hartnett DC, Wilson GWT (2005). Effects of mycorrhizal symbiosis on tallgrass prairie plant-herbivore interactions. Ecology Letters 8: 61-69. - doi: 10.1111/j.1461-0248.2004. 00690.x

Lehtilä K, Boalt E (2004). The use and usefulness of artificial herbivory in plant-herbivore studies. In: "Insects and Ecosystem Function" (Weisser WW, Siemann E eds). Springer-Verlag, Berlin Heidelberg, Germany, pp. 257-275. - doi: 10.1007/978-3-540-74004-9_13

Li S, Hartman GL, Domier LL, Boykin D (2008). Quantification of Fusarium solani f. sp. glycines isolates in soybean roots by colony-forming unit assays and real-time quantitative PCR. Theoretical and Applied Genetics 117: 343-352. - doi: 10.1007/s00122-008-0779-2

Lingua G, Franchin C, Todeschini V, Castiglione S, Biondi S, Burlando B, Parravicini V, Torrigiani P, 
Berta G (2008). Arbuscular mycorrhizal fungi differentially affect the response to high zinc concentrations of two registered poplar clones. Environmental Pollution 153: 137-147. doi: 10.1016/j.envpol.2007.07.012

Lingua G, Bona E, Todeschini V, Cattaneo C, Marsano F, Berta G, Cavaletto M (2012). Effects of heavy metals and arbuscular mycorrhiza on the leaf proteome of a selected poplar clone: a time course analysis. PLoS ONE 7: e38662. - doi: 10.1371/journal.pone.0038662

Livak KJ, Schmittgen TD (2001). Analysis of relative gene expression data using real-time quantitative PCR and the 2(-Delta Delta $C(T)$ ) method. Methods 25: 402-408. - doi: 10.1006/meth. 2001.1262

Markkola A, Kuikka K, Rautio P, Härmä E, Riotto $M$, Tuomi J (2004). Defoliation increases carbon limitation in ectomycorrhizal symbiosis of Betula pubescens. Oecologia 140: 234-240. - doi: 10.1007/s00442-004-1587-2

Nagy R, Karandashov V, Chague V, Kalinkevich K, Tamasloukht M, Jakobsen I, Levy AA, Amrhein $\mathrm{N}$, Bucher M (2005). The characterization of novel mycorrhiza-specific phosphate transporters from Lycopersicon esculentum and Solanum tuberosum uncovers functional redundancy in symbiotic phosphate transport in solanaceous species. The Plant Journal 42: 236-250. - doi: 10.1111/j.1365-313X.2005.02364.x

Pietikäinen A, Kytoviita MM, Vuoti U (2005). Mycorrhiza and seedling establishment in a subarctic meadow: effects of fertilization and defoliation. Journal of Vegetation Science 16: 175-182. - doi: 10.1111/j.1654-1103.2005.tb02353.x Regier N, Streb S, Cocozza C, Schaub M, Cherubini P, Zeeman SC, Frey B (2009). Drought tolerance of two black poplar (Populus nigra L.) clones: contribution of carbohydrates and oxidative stress defence. Plant Cell and Environment 32: 1724-1736. - doi: 10.1111/j.1365-3040.20 09.02030.x

Requena $\mathrm{N}$, Breuninger $\mathrm{M}$, Franken $\mathrm{P}$, Ocón $\mathrm{A}$ (2003). Symbiotic status, phosphate and sucrose regulate the expression of two plasma membrane $\mathrm{H}^{+}$-ATPase genes from the mycorrhizal fungus Glomus mosseae. Plant Physiology 132: 1540-1549. - doi: 10.1104/pp.102.019042

Saravesi K, Markkola A, Rautio P, Roitto M, Tuomi J (2008). Defoliation causes parallel temporal responses in a host tree and its fungal symbionts. Oecologia 156: 117-123. - doi: 10.1007/ s00442-008-0967-4

Saravesi K, Ruotsalainen AL, Cahill JF (2014). Contrasting impacts of defoliation on root colonization by arbuscular mycorrhizal and dark septate endophytic fungi of Medicago sativa. Mycorrhiza 24: 239-245. - doi: 10.1007/s00572-01 3-0536-5

Schüssler A, Schwarzott D, Walker C (2001). A new fungal phylum, the Glomeromycota: phylogeny and evolution. Mycological Research 105: 1413-1421. - doi: 10.1017/S0953756201005196 Sillo F, Zampieri E, Giordano L, Lione G, Colpaert
JV, Balestrini R, Gonthier P (2015). Identification of genes differentially expressed during the interaction between the plant symbiont Suillus luteus and two plant pathogenic allopatric Heterobasidion species. Mycological Progress 14: 106. - doi: 10.1007/s11557-015-1130-3

Smith SE, Read DJ (2008). Mycorrhizal symbiosis ( $3^{\text {rd }}$ edn). Academic Press, Amsterdam, the Netherlands, pp. 800.

Tisserant E, Kohler A, Dozolme-Seddas P, Balestrini R, Benabdellah K, Colard A, Croll D, Da Silva C, Gomez SK, Koul R, Ferrol N, Fiorilli V, Formey D, Franken P, Helber N, Hijri M, Lanfranco L, Lindquist E, Liu Y, Malbreil M, Morin E, Poulain J, Shapiro H, van Tuinen D, Waschke A, Azcón-Aguilar C, Bécard G, Bonfante P, Harrison $\mathrm{MJ}$, Küster $\mathrm{H}$, Lammers $\mathrm{P}$, Paszkowski $\mathrm{U}$, Requena N, Rensing SA, Roux C, Sanders IR, Shachar-Hill Y, Tuskan G, Young JP, Gianinazzi-Pearson V, Martin F (2012). The transcriptome of the arbuscular mycorrhizal fungus Glomus intraradices (DAOM 197198) reveals functional tradeoffs in an obligate symbiont. New Phytologist 193:755-769. - doi: 10.1111/j.1469-8137.2011.0394 8.x

Tisserant E, Malbreil M, Kuo A, Kohler A, Symeonidi $A$, Balestrini $R$, Charron $P$, Duensing $N$, Frei dit Frey N, Gianinazzi-Pearson V, Gilbert LB, Handa Y, Herr JR, Hiji M, Koul R, Kawaguchi M, Krajinski F, Lammers PJ, Masclaux FG, Murat C, Morin E, Ndikumana S, Pagni M, Petitpierre D, Requena N, Rosikiewicz P, Riley R, Saito K, San Clemente H, Shapiro H, van Tuinen D, Bécard G, Bonfante P, Paszkowski U, Shachar-Hill $Y Y$, Tuskan GA, Young JP, Sanders IR, Henrissat B, Rensing SA, Grigoriev IV, Corradi N, Roux C, Martin F (2013). Genome of an arbuscular mycorrhizal fungus provides insight into the oldest plant symbiosis. Proceedings of the National Academy of Sciences USA 110: 20117-20122. doi: $10.1073 /$ pnas.1313452110

Trocha LK, Weiser E, Robakowski P (2015). Interactive effects of juvenile defoliation, light conditions and interspecific competition on growth and ectomycorrhizal colonization of Fagus sylvatica and Pinus sylvestris seedlings. Mycorrhiza 26: 47-56. - doi: 10.1007/s00572-0150645-4

Trouvelot A, Kough JL, Gianinazzi-Pearson V (1986). Mesure du taux de mycorrhization VA d'un syste me radiculaire. Recherche de méthodes d'estimation ayant une signification fonctionnelle [Evaluation of VAM infection levels in root systems. Research for estimation methods having a functional significance] In: "Mycorrhizae: Physiology and Genetics" (GianinazziPearson V, Gianinazzi S eds). INRA Press, Paris, France, pp. 217-221. [in French]

Tuskan GA, Difazio S, Jansson S, Bohlmann J, Grigoriev I, Hellsten U, Putnam N, Ralph S, Rombauts S, Salamov A, Schein J, Sterck L, Aerts A, Bhalerao RR, Bhalerao RP, Blaudez D, Boerjan W, Brun A, Brunner A, Busov V, Campbell M, Carlson J, Chalot M, Chapman J, Chen GL, Coo- per D, Coutinho PM, Couturier J, Covert S, Cronk Q, Cunningham R, Davis J, Degroeve S, Déjardin A, Depamphilis C, Detter J, Dirks B, Dubchak I, Duplessis S, Ehlting J, Ellis B, Gendler K, Goodstein D, Gribskov M, Grimwood J, Groover A, Gunter L, Hamberger B, Heinze B, Helariutta $Y$, Henrissat B, Holligan D, Holt R, Huang $\mathrm{W}$, Islam-Faridi $\mathrm{N}$, Jones $\mathrm{S}$, Jones-Rhoades M, Jorgensen R, Joshi C, Kangasjärvi J, Karlsson J, Kelleher C, Kirkpatrick R, Kirst M, Kohler A, Kalluri U, Larimer F, Leebens-Mack J, Leplé JC, Locascio P, Lou Y, Lucas S, Martin F, Montanini B, Napoli C, Nelson DR, Nelson C, Nieminen K, Nilsson O, Pereda V, Peter G, Philippe R, Pilate G, Poliakov A, Razumovskaya J, Richardson $P$, Rinaldi C, Ritland K, Rouzé P, Ryaboy D, Schmutz J, Schrader J, Segerman B, Shin H, Siddiqui A, Sterky F, Terry A, Tsai CJ, Uberbacher E, Unneberg $P$, Vahala J, Wall K, Wessler S, Yang G, Yin T, Douglas C, Marra M, Sandberg G, Van de Peer Y, Rokhsar D (2006). The genome of black cottonwood, Populus trichocarpa (Torr. \& Gray). Science 313: 1596-1604. - doi: $10.1126 / \mathrm{sci}$ ence. 1128691

Walling SZ, Zabinski CA (2006). Defoliation effects on arbuscular mycorrhizae and plant growth of two native bunch grasses and an invasive forb. Applied Soil Ecology 32: 111-117. doi: 10.1016/j.apsoil.2005.02.017

Wardle DA (2002). Communities and ecosystems. Linking the aboveground and belowground components. Princeton University Press, Princeton, NJ, USA, pp. 408. [online] URL: http://books.google.com/books?id=b35IA aamCDCC

Warren LO, Tadic M (1970). The fall webworm, Hyphantria cunea (Durry). Arkansas Agricultural Experiment Station Bulletin 759:1-106.

Xu GH, Chague V, Melamed-Bessudo C, Kapulnik Y, Jain A, Raghothama KG, Levy AA, Silber A (2007). Functional characterization of LePT4: a phosphate transporter in tomato with mycorrhiza-enhanced expression. Journal of Experimental Botany 58: 2491-2501. - doi: 10.1093/jxb/ ermog6

Zhao S, Fernald RD (2005). Comprehensive algorithm for quantitative real-time polymerase chain reaction. Journal of Computational Biology 12: 1047-1064. - doi: 10.1089/cmb.2005.12. 1047

\section{Supplementary Material}

Tab. S1 - Relative expression of three different genes in the 15 used biological replicates.

Tab. S2 - Ct values of each technical replicate of four different genes in the 15 used biological replicates.

Link: Zampieri_1911@supploo1.pdf 